\title{
Implementing Group Investigation to Learn Reading for Senior High School Students
}

\author{
Ana Valentine Maleng ${ }^{1}$ \\ naanavalentine669@gmail.com \\ Elysa Hartati ${ }^{2}$ \\ elysa@mercubuana-yogya.ac.id \\ ${ }^{1,2}$ English Language Education Study Program, Faculty of Teacher Training and Education,
Universitas Mercu Buana Yogyakarta, Yogyakarta
}

Abstract

Students' boredom when it comes to reading long texts gives an impact on their comprehension of the text's main idea due to the use of traditional teaching and learning techniques. Therefore, this study aims to describe how Group Investigation (GI) is implemented in teaching reading, as well as to find out the students' responses toward GI in learning reading. This research focuses on finding out the evidence of how far the method affects students reading ability. The mixed-method between qualitative and quantitative approaches were used to conduct this research. The data obtained were from observation, questionnaire, interview, and documentation. The GI was conducted with group discussion and peer review. The result showed that $84.21 \%$ of students gave positive respond toward GI implementation. Based on the interview, students felt they were more motivated, engaged, and enjoyed during the reading skill lesson. Thus, GI is a good alternative to learn reading and help students' reading comprehension as well as the class environment to be more active and joyful.

Keywords: Group Investigation, Method, Reading Skill

\section{INTRODUCTION}

English as a language will become a language that is widely used for communication among people in different backgrounds at the end of the twentieth century (Harmer, 2007). This statement showed that English has an essential role in education to make people can be a part of this modern era. In learning English, four skills have to be mastered by the user, namely listening, speaking, reading, and writing. These four skills must be balanced one and another. As the country that adopted English as the foreign language (EFL), Indonesia also applies these four skills in its education field. Not only that, since Indonesia has been included in ASEAN Economic Community (AEC), it is a must for this country to make the students fluent in English. However, not all students in Indonesia can master those skills at the same time.

Grabe (2009) said that reading is an interactive process between the readers and the text, in which the readers are using their knowledge to build, create and construct the meaning. Also, it is an automatic identification skill and an array of higher-level comprehension or interpretation skills. In line with it, the other experts said that reading is the process of constructing meaning through the dynamic interaction among (1) the reader's existing knowledge; (2) the information suggested by the text being read; and (3) the context of the reading situation (Wixson, Peters, Weber, \& Roeber, 1987).

Reading is an important activity in digging up the knowledge and increasing insight. Although it has many benefits, in education, some students may say that this theory is right, and some may not since they have no interest in reading. However, in today's era, reading's skill is important because many texts used in daily life have been available in English. This means students will have difficulty in following the process of globalization if their reading skill is not upgraded or improved. 
Based on a study of Most Littered Nation in the World conducted by Central Connecticut State University 2016, it is known that Indonesia is in the position 60 of 61 countries which has a low reading interest. Moreover, according to the Human Development and Culture Ministry, people in Indonesia only read three or four times a week or equal to spending 30 minutes until 60 minutes a day reading. This means they can only finish five to nine books in a year. In education itself, students also have a low reading ability, especially in English. Megawati (2017) states that many students have difficulties in reading English texts because they only have limited vocabulary so it is hard for them to understand the meaning of the text.

From the data collected through the preliminary interview, students were asked about their usual English class were conducted. Most of the time, they were taught by the conventional learning method, which happened to be teachercentered learning. Therefore, to gain more student's interest, motivation, and comprehension toward the materials given, the Group Investigation method was suggested to be applied. Reading then became the main skill in this research. It was due to the students' boredom when it came to reading long texts and then gave an impact on their comprehension of the text's main idea. The results of observations and interviewing English teachers at private senior high schools in Surakarta, Central Java also showed that students had difficulty reading English texts. Students in one class at that school had a low reading ability related to finding the main idea of the text and specific information asked by the teacher or question provided by the book they use. Besides, the ability of reading owned by the students was also influenced by the teachers' way of teaching. This was in line with the 2013 curriculum mentioned that the purpose of reading is to understand the meaning in the simple written interpersonal and transactional discourse formally or informally, especially in the form of recount, narrative, procedure, descriptive, and report, in the context of daily life.
To make students get the meaning of the text as well as achieve the goal of the curriculum, a suitable teaching and learning process and proper technique should be applied. Many kinds of techniques can be used to teach reading, such as Learning Together, Student Teams Achievement Divisions, Group Investigation, Let's Ask and Learn Together, Jigsaw, and Reading- WritingPresentation. Amongst the variety of teaching techniques, this study tried to identify the implementation of Group Investigation. This method is one of the cooperative learning methods that involve students in relatively long-term interaction, extending for many days, weeks, or even months (Sharan \& Sharan, 1992). Group Investigation involves students working together on projects, with the class functions as a group or groups. Working together with peers will make students feel happy, assume that it can be a fun activity to be done without pressure from the teachers. The Group Investigation technique requires the students to make small groups, plan and implement their investigation, synthesize the group member's findings, and make a presentation to the entire class.

By using this technique, teachers are expected to create a smooth and enjoyable teaching and learning atmosphere, especially in the reading activity. When applying this technique teacher should put the students with different levels of ability together in one group. Group Investigation not only makes the students interested in the reading activity, but it also makes the teachers should think creatively to choose the best materials for students to increase the student's way of thinking to solve the problems. This means that Group Investigation does not only bring benefit for students, but also teachers themselves.

Previous GI implementation on English course has been done by Nisfah (2009) and Iswardati, (2016). Both of the researches showed positive feedback and result. Nisfah (2009) suggested that GI had given so much improvement, especially new atmosphere for students in learning writing. The students' responses were positive as they became more interested in developing their English writing 
skills. It is also in line with Iswardati, (2016) where she used classroom action research and done in two cycles when implementing GI. After the execution, she found that it improved students' speaking ability that can be seen in their pronunciation, grammar, vocabulary, and fluency. Not only did it improve students' speaking skill, but it also encouraged students to participate in a speaking activity.Then, it is known that the implementation of GI had performed a good another possibility for better teaching English skill, such as writing and speaking. Therefore, this study explores more on using GI in different fields of English skill, which is reading. It elaborates more on students' responses, including their experience, emotion, and lesson comprehension. It is hoped that the use of GI also attains a better teaching and learning experience in a similar way as the previous study's outcomes.

Moreover, if the students' reading ability is still low, then the purposes of the curriculum also cannot be achieved and it can make the quality of education in Indonesia decreased. According to OECD (2016), there is only 1\% Indonesian adult who has adequate literacy level that can integrate, interpret, and synthesize information from a longer text. This has made Indonesia rank as low as 60 out of 61 countries based on Central Connecticut State University (2016) on "The World Most Literate Nation Study" (John W Miller, n.d.). This condition is believed to cause severe effects, such as lower human productivity, due to poor literacy, information and knowledge will hardly be acquired or limited. This will lead to another problem, the failure to optimize the potential for themselves and their society. Also, education could easily stop, for instance, higher school drop level. Without literacy awareness, the importance of education is not built from within yourself but rather as normative, thus lead to the basis of unemployment.

Based on the description aforementioned, this research is conducted to implement Group Investigation in one school in Central Java. This study aims to describe how Group Investigation is implemented in teaching reading, as well as to find out the students' responses toward Group
Investigation in learning reading. Therefore, the implementation of Group investigation is expected to create a new learning and teaching process so that teachers can teach reading using the suitable technique and students can have a good reading ability as well as they can learn something by themselves through reading.

\section{METHODOLOGY}

This research used a mixed-method approach to gather and analyze the data. According to Gunnell, (2016), mixed methods is a systematic integration of mixing between quantitative and qualitative data within a single investigation. The mixedmethod utilizes these data than do separate quantitative and qualitative collection and analysis.

This study was conducted at the XI IPA grade students in the academic year of 2019/2020 in the even semester. This class was chosen based on the teacher's recommendation due to teachers' difficulties and students' low reading comprehension. In this class, there are eleven males and eight females. All of the students were between the age of 16-18 years old.

To obtain the data, this research used observation, questionnaire collection, interviews, and documentation. In line with a qualitative method, the data collecting technique was done by observing the teaching and learning process in the classroom and interviewing 4 sample students as well as a quantitative method by asking the students' response in form of a questionnaire toward the model of Group Investigation.

The questionnaire was designed to be filled out by the students to see their responses towards learning reading through GI. There were 10 items designed with Yes or No answers based on Nurmalasari (2016) with focusing on their knowledge toward the GI model. At the end of the second meeting, the questionnaire was carried out. The students were guided and explained about the questionnaire items before filling them out so that they understood the items very well.

The interview was designed to see more detail on their responses towards learning reading 
through GI. When learning biography text, the teacher divided the class into 4 groups, where each group consisted of 4 to 5 students. Each group should choose their leader on their own, without any teacher's intervention. These leaders, later on, were chosen as the sample student to be interviewed. There were 20 items of semistructured questions designed based on Pratama (2013) with focusing on their experience and feelings when GI was implemented in their lesson. The interview was done in Indonesian to ease students when answering the questions as well as to get in-depth and genuine answers.

The documentation was taken during the class activity. It aimed to picture how the students were engaged in the project work. According to Helm et al. (1997), documentation reveals how the students planned, carried out, and completed the displayed work. Documentation makes it possible for others to become aware of the students' experiences in the classroom

The data obtained from this research was analyzed by using Miles et al. (2014) theory correlated to the data analysis in qualitative research, there were steps of data analysis: data reduction, data display, and conclusion/verification. Data reduction was the activity of selecting, abstracting, and restudying the transcription or field notes during the process of observing and documenting. The second stage was data display which was about organizing and compressing the summary in data reduction. The third step was drawing conclusions and verification which was the last step of analyzing qualitative research. It was about finding and writing to summarize after two processes before done.

\section{RESULT AND DISCUSSION}

This research was conducted within the English subject in class XI IPA of Senior High School. The meeting topic was biography texts which were placed on 2 meetings according to the teacher's lesson plan. These meetings were different from their regular class due to the implementation of
Group Investigation to help students' reading comprehension.

\section{The Implementation of Group Investigation}

In the research, students were given time to discuss more with their friends about the materials. The teacher brought up the topic of Biography Text. In this research, the lesson focused more on student-centered learning, thus the teacher became the facilitator, only to stir and make sure the materials were in track.

\section{Group Investigation in the First Meeting}

In the first meeting, the teacher explained biography texts. It was done because explanation of biography texts was needed by students. The teacher was also asked some questions about some famous people by providing the materials on screen. Some questions related to the biography text were asked to the students. It was done to catch student's attention and to elicit their knowledge related to the texts.

Before starting the lesson, the teacher introduced the new learning method, Group Investigation, which would be applied in the first and second meeting. She explained that the course would require a lot of peer discussion and students were needed to be active. To make the discussion flowed smoothly, the teacher had already made the groups based on their reading comprehension achievement. This aimed the students not only gathered with their preference peers, but rather with those who could help them to improve each other reading comprehension. Therefore, they should be around with their group in the first and second meeting when learning biography texts.

In the next stage, the teacher distributed a biography text for all students. The students were given some time to read the text and comprehend the main idea. After that, a medium of short biography video was also played to make them understand more on the main idea of the text. Then, the teacher asked the students to identify the generic structure and language features. 
Students were given time to discuss with their peers, thus it made the class a bit noisy, but the teacher always checked each groups' progress. However, the class felt joyful and fun, whilst they were only learning the basic material of the topic. From the observation, most of the group member were active and tried to share their opinion toward the topic.

The students were solving the problems in their group, and the teacher made sure their discussion went on the right path. After each group finished discussing their work, the teacher gathered all students to discuss together on the answers. Most of the group answered the task with the right answer. In the end of this stage, students needed to answer some questions related to the texts. They were asked to identify the elements of the text (topic, vocabulary, generic structures and the goal). Then, the students had to answer the task related to the text.

In the end of the discussion, the teacher summarized the materials. She also gave feedback to the students and their result with positive praise, such as "You did a good job today, I'm very happy with your activity in the class." Students were also given individual homework to write a biography text about one member of their families. Then, the class was dismissed.

\section{Group Investigation in the Second Meeting}

In the second meeting, the teacher tried to encourage the students to be active in the class by asking questions about the lesson from the previous meeting. Most of the students still remembered the materials that they had learned before. In the next stage, the teacher asked the students to gather again with their previous group consisting of 4 to 5 people. Then, 4 to 5 different texts were distributed for each group. The texts were biographical recount texts in a full story about one figure but from different sources. Each students were given some time to read their text. They were asked to find some information about the figure and they should inform it to their friends in the group. Each student had specific and unique information about the figure so that this would complete and enrich their knowledge about the figure.

This task gave students more excitement, and more serious class, because they had to focus on their work as well as their group result. Students gave attention to their texts and they had to share it with their other friends. The class were quiet because the students were reading carefully, they seemed did not want to miss any specific information, since what they read were different from each other.

After individual reading section, they were given discussion time. Here, each member of the group should tell their materials. Each group was enthusiast to listen each different stories from their members. The class was active, and they supported each other to speak up. The condition, thus, made the students enjoy sharing and discussion section, since they already felt close with their friends. When all member of the group had already stated their data from the text, they should gather all information to make a whole and complete biography text. In the end of the discussion, one of the each group member should share their group's result.

Figure 1

Students' Activity in GI Implementation

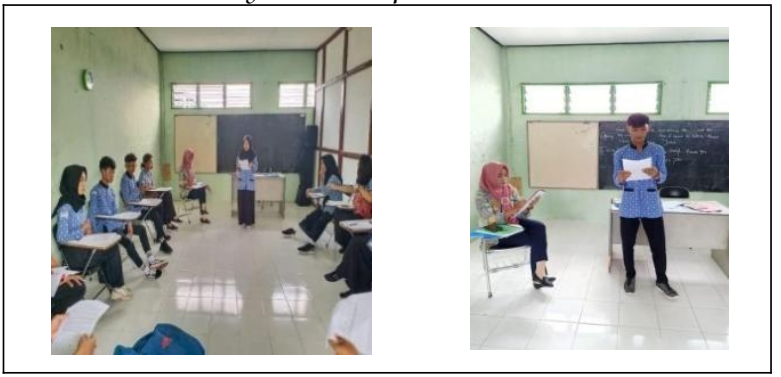

The teacher then gave some feedback about their learning progress. In the end of the discussion, the teacher summarized the materials. She also gave feedback to the students and their result with positive praise. The students were also given individual homework to about the next meeting topic then, the class was dismissed.

\section{Students' Response from Questionnaire}


Students ' responses were seen based on the questionnaire that has been shared at the end of the lesson. The student's learning questionnaire were filled by 19 students after learning with the model of Group Investigation on the reading skill in class XI IPA of Senior High School. The result obtained is provided in Table 1.

Table 1

Students' Questionnaire Responses Towards GI Implementation

\begin{tabular}{|c|c|c|c|c|c|}
\hline \multirow{3}{*}{ No } & \multirow{3}{*}{ Statement } & \multicolumn{4}{|c|}{ Response } \\
\hline & & \multicolumn{2}{|c|}{ Yes } & \multicolumn{2}{|l|}{ No } \\
\hline & & Total & $(\%)$ & Total & $(\%)$ \\
\hline 1 & $\begin{array}{l}\text { The Group Investigation learning model is a new } \\
\text { learning model for me }\end{array}$ & 16 & 84.21 & 3 & 15.78 \\
\hline 2 & $\begin{array}{l}\text { I find it easier to understand the English reading } \\
\text { material taught }\end{array}$ & 16 & 84.21 & 3 & 15.78 \\
\hline 3 & I find it easier to interact with friends in the group & 17 & 89.47 & 2 & 10.52 \\
\hline 4 & I feel more active when studying English reading text & 15 & 78.94 & 4 & 21.05 \\
\hline 5 & $\begin{array}{l}\text { The Group Investigation learning model increases } \\
\text { interest in learning to read English reading material }\end{array}$ & 15 & 78.94 & 4 & 21.05 \\
\hline 6 & $\begin{array}{l}\text { I feel motivated in learning English reading material by } \\
\text { using the Group Investigation learning model }\end{array}$ & 16 & 84.21 & 3 & 15.78 \\
\hline 7 & $\begin{array}{l}\text { I like the learning model of Group Investigation to } \\
\text { study English reading text }\end{array}$ & 17 & 89.47 & 2 & 10.52 \\
\hline 8 & $\begin{array}{l}\text { I am interested in following the next lesson with the } \\
\text { Group Investigation learning model }\end{array}$ & 17 & 89.47 & 2 & 10.52 \\
\hline 9 & I feel the difference between learning using & 16 & 84.21 & 3 & 15.78 \\
\hline 10 & $\begin{array}{l}\text { The Group Investigation learning model makes me } \\
\text { excited and not bored while the learning process is } \\
\text { taking place }\end{array}$ & 17 & 89.47 & 2 & 10.52 \\
\hline Ave & & 84.21 & & 15.78 & \\
\hline
\end{tabular}

From the data, it is known that most students $(84.21 \%)$ thought Group Investigation helped them on learning reading skills. Most of the students loved to learn using the Group Investigation model because the study model was student-centered. Students should seek their own information from the topics given by the teachers in each group, making students more active than teacher-centered learning, and facilitate the ability to understand the reading text material rather than using conventional models.

Through exchanging thoughts and sharing knowledge with each other, students got more

enjoyment. In addition, students in their classes were required to read explicitly on topics closely connected to issues around them through the implementation of this technique. They may also develop their reading skills by debating, reviewing, posing, and asking or answering questions. This model not only improves students' awareness but also creates social skills that are very important for integrating the context of texts in life.

\section{Student's Responses from Interview}

An interview was also conducted with the students to triangulate the data to make it more 
valid. It is done to students and teachers by giving semi-structural questions to find the problem. Interview to students was held in random sampling, consisting of 4 students.

The interview consisted of 20 set questions. The students were given structural questions which led to getting their response toward the implementation of Group Investigation on teaching English reading skills. Some interviews were conducted with the students to obtain their comments on the reading class.

Group Investigation has been effective in enhancing the students' comprehension of reading texts. Through communicating with their peers and sharing their information with them, they could comprehend the knowledge. The technique also increased their interest by doing the research throughout the lesson to understand the texts.

The teacher provided the students with a task to read unique and specific texts for every group member in order to activate all students in each group. The students appreciated the learning process because they liked new activity as seen in the interview transcript. The teacher did a group task that took the form of an essay during this process to include students more in the discussions. The task helped them to understand the biographical text that was aimed at investigating all the data on the figure. The goal of these questions was to improve the understanding of the biography text. It was submitted for review after the assignment was completed.

Students typically increase their interest in the learning process. Such exercises helped them appreciate the information they received and they could share with others in their community what they learned. Functioning in a group meant that students were able to get more understanding about the text from their friends' input.

The students stated that they were encouraged to participate in the classroom activities. The students may even reduce the difficulties of answering to the tasks and the reading comprehension test. Then the enthusiasm of the students also grew while reading English texts. On the results of the interview, students feel more comfortable as they read the text and answer questions.

\section{Discussion}

Group Investigation (GI) Model accounts as Cooperative Learning where students work together to find problem-solving with analysis with group research. Group Investigation (GI) model templates four or five members of each group from various backgrounds or levels. The group could grow good relationship based on the same interest or friendship, students felt more relaxed in their groups and likely engage with those who have the same style of work.

Group Investigation has resulted in increasing the students' comprehension and engagement in reading English text. Group Investigation offered a situation for students that could allow them to be involved in learning reading skills. They were taught to communicate with each other and with the teacher. They got chances to exchange ideas and information about the materials with others.

In the beginning, the students had been encouraged to express the goals of their lessons through media, accompanied by questions and answers. The students' attention to the lessons was also increased. The students have become more motivated to work together through GI. It allowed students, through sharing their ideas, teaching each other knowledge, and prompting students to read the text, and also help their other friends. During the lesson, the students were encouraged, confident, and actively engaged.

The mixed skills group could help slow learners to understand reading material and encourage them. This also contributes to reading comprehension improvement. The group of mixed abilities also prevents students from boredom. In addition, when studying in groups or in pairs, students were more interested in joining the class. Encouraging students and facilitating enjoyable learning activities are more likely to increase their engagement in the lessons. The students were not scared to interact positively with their peers. They 
may exchange their knowledge and at the same time, they improve their comprehension.

The GI method has successfully attracted the attention of students so that they have taken care of the material presented. As students' interests in the subject have grown, they have no more spoken to their peers about other subjects. Thus the noise of the class was reduced. The class was therefore less monotonous since the teacher did not dominate the class. The teacher helped explain the text a little bit. The teacher did not give the answer straight away. The teacher encourages the learner to find the answers by themselves.

Therefore, students were getting benefit from the English course through the GI method. During the teaching and learning process, they were well engaged. For instance, they will ask questions when they do not understand, answer questions actively, and openly become volunteers. It was in accordance with Nelli \& Hartati (2018), where students' participation increased when students were given interesting learning methods and certain rewards.

The students were often willing to teach or inform if their friends have difficulties while learning. They became more interested to read as they had friends who would help them to comprehend the text. It became more interesting the learning of reading English text. It was not simply reading texts, practicing translation, and answering reading questions, but also carrying out various activities that could motivate all students to work in groups.

Using the GI method built a fun and enjoyable learning environment. As the students became focus on the process, they did not rely on the teacher to learn English. Students may assist other friends in finishing projects and understanding materials. As a result, they became more confident and willing to study English actively.

\section{CONCLUSION}

Based on the results of research and discussion, it can be concluded that Group Investigation methods of learning could help the students' reading comprehension. The students were more driven to read by cooperative learning. This encouraged students to support other friends by sharing their opinions, skills, and encouraging them to read the text. During the reading class, students got motivated, confident and engaged, because they enjoyed the lesson. The students also felt helped by learning with the GI method. This means that the teacher can encourage students to work in groups or pairs so that they can discuss learning materials with their friends. At last, it can be noted that GI is a good alternative to teach reading and help students' reading comprehension as well as class environment to be more active and joyful.

\section{REFERENCES}

Grabe, W. (2009). Reading in a second language (moving from theory to practice). Cambridge University Press.

Gunnell, M. (2016). Research Methodologies: A Comparison of Quantitative, Qualitative and Mixed Methods. https://www.linkedin.com/pulse/researchmethodologies-comparison-quantitativemixed-methods-gunnell

Harmer, J. (2007). The Practice of English Language Teaching (4th ed.). Pearson Longman.

Helm, J. H., Beneke, S., \& Steinheimer, K. (1997). Documenting children's learning. Childhood Education, 73(4), 200-205. https://doi.org/10.1080/00094056.1997.1052 $\underline{1093}$

Iswardati, I. (2016). The implementation of group investigation to improve the students' speaking skill. Dinamika Ilmu, 16(2), 245. https://doi.org/10.21093/di.v16i2.551

John W Miller. (March 9, 2016). World's Most Literate Nations Ranked. Retrieved June 29, 2020, from https://webcapp.ccsu.edu/?news=1767\&data 
Megawati, M. (2017). The improving students' reading comprehension through grammar translation method. English Education: Journal of English Teaching and Research, 2(2), 95-108.

https://doi.org/10.29407/jetar.v2i2.833

Miles, M. B., Huberman, A. M., \& Saldana, J. (2014). Qualitative Data Analysis: A Methods Sourcebook. Sage.

Nelli, N., \& Hartati, E. (2018). Improving students' reading comprehension through cooperative learning strategies using numbered heads together. JELE (Journal of English Language and Education), 4(1), 28-36. https://doi.org/10.26486/jele.v4i1.317

Nisfah, I. J. (2009). The Ability of Writing Recount Text of the $11^{\text {th }}$ Grade Students of SMA Muhammadiyah Kudus in the Academic Year 2008/2009 Taught by Using Group Investigation Method [Thesis Muria Kudus University].
Nurmalasari, N. (2016). Pengaruh Model Pembelajaran Group Investigation terhadap Hasil Belajar Siswa Kelas XI pada Materi Sistem Koloid di MAN Indrapuri [Thesis UIN Ar-Raniry Banda Aceh]. http://library.arraniry.ac.id

OECD. (2016). Skills Matter: Further Results from the Survey of Adult Skills. https://www.oecd.org/skills/piaac/Skills Matter Further Results from the Survey of Adult Skills.pdf

Pratama, A. (2013). Using Cooperative Learning Strategies To Improve Reading Comprehension Of The Seventh Grade Students At Smp N 1 Borobudur In The Academic Year Of 2012/2013 [Thesis Universitas Negeri Yogyakarta].

Sharan, Y., \& Sharan, S. (1992). Expanding Cooperative Learning Through Group Investigation. Teachers College Press. https://eric.ed.gov/?id=ED367509 
